\title{
Saccharopolyspora qijiaojingensis sp. nov., a halophilic actinomycete isolated from a salt lake
}

\author{
Correspondence \\ Wen-Jun Li \\ wjli@ynu.edu.cn \\ or \\ liact@hotmail.com
}

\author{
Shu-Kun Tang, ${ }^{1}$ Yun Wang, ${ }^{2}$ Jin-Yuan Wu, ${ }^{1}$ Lan-Lan Cao, ${ }^{2}$ Kai Lou, ${ }^{2}$ \\ Li-Hua Xu, ${ }^{1}$ Cheng-Lin Jiang ${ }^{1}$ and Wen-Jun $\mathrm{Li}^{1}$
${ }^{1}$ The Key Laboratory for Microbial Resources of the Ministry of Education, PR China, and Laboratory for Conservation and Utilization of Bio-resources, Yunnan Institute of Microbiology, Yunnan University, Kunming, Yunnan 650091, PR China
${ }^{2}$ Xinjiang Institute of Microbiology, Xinjiang Academy of Agricultural Science, Urumqi, Xinjiang 830091, PR China

\begin{abstract}
A halophilic actinomycete strain, designated YIM $91168^{\top}$, was isolated from a salt lake in Xinjiang province, north-west China. The isolate grew at $20-40{ }^{\circ} \mathrm{C}, \mathrm{pH} 5-8$ and $6-22 \%(\mathrm{w} / \mathrm{v}) \mathrm{NaCl}$; there was no growth in the absence of $\mathrm{NaCl}$. The whole-cell hydrolysate contained mesodiaminopimelic acid, galactose and arabinose. The major fatty acids were iso- $C_{15: 0}$, iso- $C_{16: 0}$ and iso- $\mathrm{C}_{17: 0}$. MK-9 $\left(\mathrm{H}_{4}\right)$ was the predominant menaquinone and the genomic DNA G $+\mathrm{C}$ content was $70.1 \mathrm{~mol} \%$. These chemotaxonomic data, together with its morphological properties, were consistent with the assignment of strain YIM $91168^{\top}$ to the genus Saccharopolyspora. Phylogenetic analysis based on 16S rRNA gene sequences revealed that strain YIM $91168^{\top}$ had highest sequence similarity (95.4\%) with Saccharopolyspora gregorii NCIB $12823^{\top}$, and showed lower 16S rRNA gene sequence similarity (93.0-95.1\%) with the other species of the genus Saccharopolyspora. On the basis of evidence from this polyphasic study, the novel species Saccharopolyspora qijiaojingensis sp. nov. is proposed. The type strain is YIM $91168^{\top}$ (=DSM $45088^{\top}=$ KCTC $19235^{\top}$ ).
\end{abstract}

The genus Saccharopolyspora was first described by Lacey \& Goodfellow (1975). At the time of writing, it comprises 16 species. The following species have been described in the last two years: Saccharopolyspora antimicrobica (Yuan et al., 2008), S. cebuensis (Pimentel-Elardo et al., 2008), S. shandongensis (Zhang et al., 2008), S. endophytica (Qin et al., 2008), S. halophila (Tang et al., 2009), S. jiangxiensis (Zhang et al., 2009) and S. rosea (Yassin, 2009). Members of the genus Saccharopolyspora are aerobic, Gram-positive, non-acid-fast actinomycetes. The substrate mycelium fragments into rod-shaped elements and the aerial mycelium forms bead-like chains of spores. Whole-cell hydrolysates contain meso-diaminopimelic acid, galactose and arabinose. MK-9 $\left(\mathrm{H}_{4}\right)$ is the predominant menaquinone. The DNA G + C content is $66-77 \mathrm{~mol} \%$ (Lacey \& Goodfellow, 1975; Korn-Wendisch et al., 1989).

Strain YIM $91168^{\mathrm{T}}$ was isolated from a soil sample collected from Qijiaojing salt lake in Xinjiang Province, north-west China (GPS coordinates for the sampling

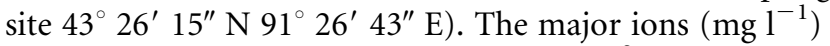
were $\mathrm{Na}^{+}(107788.4), \mathrm{K}^{+}$(1658.3), $\mathrm{Mg}^{2+}$ (10 357.6), $\mathrm{Cl}^{-}$(185 631.9), $\mathrm{SO}_{4}^{2-}$ (16 381.7) and $\mathrm{HCO}_{3}^{-}$(318.1). The

The GenBank/EMBL/DDBJ accession number for the 16S rRNA gene sequence of strain YIM $91168^{\top}$ is EF687715. strain was isolated after 3 weeks of incubation at $28{ }^{\circ} \mathrm{C}$ on cellulose-casein-multisalts (CCMS) medium, described by Tang et al. (2008). The strain was maintained on International Streptomyces Project (ISP) medium 4 agar slants containing $10 \%(\mathrm{w} / \mathrm{v}) \mathrm{NaCl}$ at $4{ }^{\circ} \mathrm{C}$ and as suspensions of mycelium fragments in glycerol $(20 \%$, $\mathrm{v} / \mathrm{v})$. Biomass for chemical and molecular studies was obtained by cultivation in shaken flasks (about 150 r.p.m.) using ISP medium $4[10 \%(\mathrm{w} / \mathrm{v}) \mathrm{NaCl}, \mathrm{pH} 7.5]$ at $28{ }^{\circ} \mathrm{C}$ for 2 weeks.

Cultural characteristics were determined after 3-4 weeks by methods used in the ISP (Shirling \& Gottlieb, 1966). All media were supplemented with $10 \%(\mathrm{w} / \mathrm{v}) \mathrm{NaCl}$ for growth. The colours of substrate and aerial mycelia and any soluble pigments produced were determined by comparison with chips from the ISCC-NBS colour charts (Kelly, 1964). Strain YIM $91168^{\mathrm{T}}$ grew well on ISP 4 agar and potato agar and showed no growth on Czapek's agar, ISP 2 agar, nutrient agar and oatmeal agar. Aerial mycelium was less abundant on ISP 4 agar. The colour of aerial and substrate mycelia was white-yellow. No soluble pigments were produced. Morphological characteristics of strain YIM $91168^{\mathrm{T}}$ were observed by light microscopy (model BH 2; Olympus) and scanning electron microscopy (JSM5600LV; JEOL) after 21 days growth on ISP 4 agar 
medium containing $10 \%(\mathrm{w} / \mathrm{v}) \mathrm{NaCl}$. Morphological features of YIM $91168^{\mathrm{T}}$ were consistent with those of members of the genus Saccharopolyspora described previously (Korn-Wendisch et al., 1989). The substrate mycelium was well developed, but fragmented into rodshaped elements. The aerial mycelium formed bead-like chains of spores (Fig. 1).

Growth was tested at 4,10,15,20,28,37,40,45, 55 and $65{ }^{\circ} \mathrm{C}$ on ISP medium 4 containing $10 \%(\mathrm{w} / \mathrm{v}) \mathrm{NaCl}$. For $\mathrm{NaCl}$ tolerance experiments, ISP medium 4 was used as the basal medium, with $\mathrm{NaCl}$ added at $0-30 \%(\mathrm{w} / \mathrm{v})$, at intervals of $1 \%$. The $\mathrm{pH}$ range for growth was investigated between $\mathrm{pH} 4.0$ and 10.0 at intervals of $1 \mathrm{pH}$ unit, using the following buffers: $\mathrm{pH}$ 4.0-5.0, $0.1 \mathrm{M}$ citric acid/0.1 M sodium citrate; $\mathrm{pH}$ 6.0-8.0, $0.1 \mathrm{M} \mathrm{KH}_{2} \mathrm{PO}_{4} / 0.1 \mathrm{M} \mathrm{NaOH}$; pH 9.0-10.0, 0.1 M NaHCO $3 / 0.1 \mathrm{M} \mathrm{Na}_{2} \mathrm{CO}_{3}$. Media and procedures used for determination of physiological features and carbon source utilization were those described by Williams et al. (1989). Antibiotic susceptibility was determined by the method of Williams (1967). Strain YIM $91168^{\mathrm{T}}$ grew at $20-40{ }^{\circ} \mathrm{C}$, pH $5.0-8.0$ and $6-22 \%$ $\mathrm{NaCl}$; there was no growth in the absence of $\mathrm{NaCl}$, showing that strain YIM $91168^{\mathrm{T}}$ is moderately halophilic. The organism can be distinguished from members of Saccharopolyspora with validly published names by using a battery of phenotypic tests (Table 1).

Isomers of diaminopimelic acid and whole-cell sugars were analysed according to the procedures developed by Hasegawa et al. (1983). Polar lipids were extracted and examined by two-dimensional TLC and identified using previously described procedures (Minnikin et al., 1984). Menaquinones were isolated according to Minnikin et al. (1984) and separated by HPLC (Kroppenstedt, 1982). For fatty acid analysis, cells of strain YIM $91168^{\mathrm{T}}$ were cultured on tryptic soy agar (TSA; Difco) containing $10 \% \mathrm{NaCl}$ at $28{ }^{\circ} \mathrm{C}$ for 4 days. Cellular fatty acid analysis was performed as described by Sasser (1990) using the Microbial Identification System (MIDI). Strain YIM $91168^{\mathrm{T}}$ con-

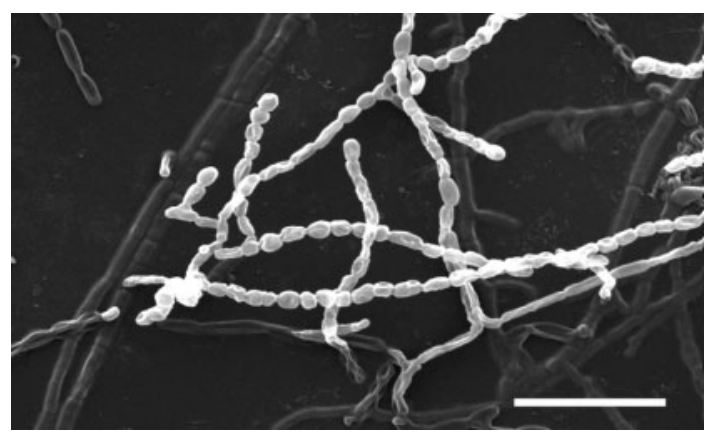

Fig. 1. Scanning electron micrograph of fragmented substrate mycelium and bead-like spore chains of strain YIM $91168^{\top}$ grown on ISP medium $4(10 \% \mathrm{NaCl}, w / v)$ for 21 days at $28^{\circ} \mathrm{C}$. Bar, $5 \mu \mathrm{m}$. tained meso-diaminopimelic acid as the cell-wall diamino acid, with galactose and arabinose as the major whole-cell sugars (wall chemotype IV; Lechevalier \& Lechevalier, 1970). The phospholipids were diphosphatidylglycerol, phosphatidylcholine, phosphatidylinositol, phosphatidylethanolamine, phosphatidylinositol mannosides and an unknown phospholipid, representing phospholipid pattern III (Lechevalier et al., 1977). The predominant menaquinone was MK-9 $\left(\mathrm{H}_{4}\right)(72.0 \%)$; minor amounts of MK$8\left(\mathrm{H}_{4}\right)(17.5 \%)$, MK-9 $\left(\mathrm{H}_{6}\right)(9.7 \%)$ and MK-9 $\left(\mathrm{H}_{8}\right)(2.0 \%)$ were detected. Strain YIM $91168^{\mathrm{T}}$ had a cellular fatty acid profile that contained major amounts of branched fatty acids and minor amounts of straight-chain, unsaturated and methyl fatty acids; it contained iso- $\mathrm{C}_{15: 0}(27.0 \%)$, iso$\mathrm{C}_{17: 0}(18.9 \%)$, iso- $\mathrm{C}_{16: 0}(13.9 \%)$, anteiso- $\mathrm{C}_{17: 0}(9.3 \%)$, $\mathrm{C}_{16: 0} \quad(7.7 \%), \mathrm{C}_{18: 0} \quad(4.4 \%)$, anteiso- $\mathrm{C}_{15: 0}$ (3.6\%), $\mathrm{C}_{16: 1} \omega 7 c /$ iso- $\mathrm{C}_{15: 0} \quad 2-\mathrm{OH} \quad(2.7 \%), \quad \mathrm{C}_{17: 0} \quad(2.6 \%)$, $\mathrm{C}_{18: 1} \omega 9 c(2.3 \%), 10$-methyl $\mathrm{C}_{16: 0}(1.4 \%), \mathrm{C}_{14: 0}(1.3 \%)$, $\mathrm{C}_{18: 2} \omega 6,9 c /$ anteiso- $\mathrm{C}_{18: 0}(1.2 \%)$, anteiso- $\mathrm{C}_{16: 0}(1.1 \%)$, $\mathrm{C}_{17: 1} \omega 8 c(1.1 \%)$, iso- $\mathrm{C}_{14: 0}(1.0 \%)$ and $\mathrm{N}$-alcohol $\mathrm{C}_{16: 0}$ $(0.7 \%)$. This pattern represents fatty acid type $2 \mathrm{~d}$, according to Kroppenstedt (1985). The chemotaxonomic data for strain YIM $91168^{\mathrm{T}}$ are consistent with its assignment to the genus Saccharopolyspora (Lacey \& Goodfellow, 1975; Korn-Wendisch et al., 1989).

Extraction of genomic DNA and PCR amplification of the $16 \mathrm{~S}$ rRNA gene were done as described by Li et al. (2007). Multiple alignments with sequences of the most closely related Saccharopolyspora species and calculations of levels of sequence similarity were carried out using EzTaxon server 2.0 (Chun et al., 2007). Phylogenetic analyses were performed using three tree-making algorithms, the neighbour-joining (Saitou \& Nei, 1987), maximum-likelihood (Felsenstein, 1981) and maximum-parsimony (Fitch, 1971) methods. A phylogenetic tree was constructed using the neighbour-joining method of Saitou \& Nei (1987) from $K_{\text {nuc }}$ values (Kimura, 1980) using MEGA version 4.0 (Tamura et al., 2007). The topology of the phylogenetic tree was evaluated by the bootstrap resampling method of Felsenstein (1985) with 1000 replicates. Genomic DNA of strain YIM $91168^{\mathrm{T}}$ for the determination of $\mathrm{G}+\mathrm{C}$ content was prepared according to the method of Marmur (1961). The $\mathrm{G}+\mathrm{C}$ content of the DNA was determined by reversed-phase HPLC of nucleosides according to Mesbah et al. (1989). The $\mathrm{G}+\mathrm{C}$ content of the DNA was $70.1 \mathrm{~mol} \%$.

Results of 16S rRNA gene sequence comparison clearly demonstrated that strain YIM $91168^{\mathrm{T}}$ is a member of the genus Saccharopolyspora. In the phylogenetic tree based on the neighbour-joining algorithm, strain YIM $91168^{\mathrm{T}}$ formed a monophyletic clade with Saccharopolyspora gregorii $\mathrm{NCIB} 12823^{\mathrm{T}}$, and the two strains shared a branch with a bootstrap value of $70 \%$ (Fig. 2). Topologies of phylogenetic trees built using the maximum-likelihood and maximum-parsimony algorithms were similar to that of the tree constructed by neighbour-joining analysis (not shown). The 16S rRNA gene sequence similarity between 
Table 1. Differential phenotypic and chemotaxonomic characteristics of strain YIM $91168^{\top}$ and its closest neighbours in the genus Saccharopolyspora

Strains: 1, YIM $91168^{\mathrm{T}}$; 2, S. gregorii NCIB (now NCIMB) $12823^{\mathrm{T}}$; 3, S. rectivirgula ATCC $33515^{\mathrm{T}} ; 4$, S. taberi DSM $43856^{\mathrm{T}}$; 5 , S. erythraea NRRL $2338^{\mathrm{T}}$; 6, S. spinosporotrichia AS4.198 $8^{\mathrm{T}}$. Data for strain YIM $91168^{\mathrm{T}}$ are from this study; data for the other strains are from Goodfellow et al. (1989), Korn-Wendisch et al. (1989), Labeda (1987) and Zhou et al. (1998). +, Positive; -, negative; ND, no data available. All strains degrade xanthine and utilize D-galactose, maltose and L-rhamnose.

\begin{tabular}{|c|c|c|c|c|c|c|}
\hline Characteristic & 1 & 2 & 3 & 4 & 5 & 6 \\
\hline Spore arrangement & Straight & Hooks or flexuous hyphae & Straight & NA & Open spirals & Spirals \\
\hline \multicolumn{7}{|l|}{ Colour of: ${ }^{*}$} \\
\hline Aerial mycelium & $\mathrm{W}-\mathrm{Y}$ & $\mathrm{W}-\mathrm{Y}$ & $\mathrm{Y}-\mathrm{O}$ & NA & P-BRG-W & $\mathrm{W}-\mathrm{G}$ \\
\hline Substrate mycelium & $\mathrm{W}-\mathrm{Y}$ & $\mathrm{C}-\mathrm{BF}$ & $\mathrm{W}-\mathrm{LP}$ & $\mathrm{C}-\mathrm{Y}$ & OY-RBR & $\mathrm{BR}-\mathrm{R}$ \\
\hline Soluble pigment & None & None & None & $\mathrm{O}-\mathrm{R}$ & Y-POBR & BR \\
\hline \multicolumn{7}{|l|}{ Degradation of: } \\
\hline Adenine & - & - & - & + & + & - \\
\hline Casein & - & + & - & + & - & + \\
\hline Chitin & - & ND & - & + & + & - \\
\hline Hypoxanthine & + & + & + & + & + & ND \\
\hline Starch & - & + & - & + & + & - \\
\hline Tyrosine & - & + & + & + & + & - \\
\hline Urea & - & - & + & + & + & ND \\
\hline Nitrate reduction & - & - & + & + & + & - \\
\hline Temperature for growth $\left({ }^{\circ} \mathrm{C}\right)$ & $20-40$ & $10-35$ & $37-63$ & $20-45$ & $20-42$ & $28-37$ \\
\hline $\mathrm{NaCl}$ tolerance $(\% \mathrm{w} / \mathrm{v})$ & $6-22$ & $0-13$ & $0-10$ & $0-7$ & $0-5$ & $0-3$ \\
\hline \multicolumn{7}{|l|}{ Utilization of: } \\
\hline L-Arabinose & - & + & - & - & + & - \\
\hline Lactose & + & - & + & + & - & - \\
\hline Sucrose & - & + & + & + & + & + \\
\hline D-Xylose & - & + & + & + & + & + \\
\hline DNA G $+\mathrm{C}$ content $(\mathrm{mol} \%)$ & 70.1 & 74 & 70.4 & 70.8 & 71.1 & 70.4 \\
\hline
\end{tabular}

${ }^{\star} \mathrm{BF}$, Buff; BR, brown; C, colourless; G, grey; LP, light pink; O, orange; P, pink; R, red; w, white; $\mathrm{Y}$, yellow.

strain YIM $91168^{\mathrm{T}}$ and its closest neighbour, S. gregorii NCIB $12823^{\mathrm{T}}$, was $95.4 \%$, while the similarity with the type strains of other species of the genus was $93.0-95.1 \%$.

It is evident from the phenotypic, chemotaxonomic and phylogenetic data (Table 1 and Fig. 2) that strain YIM $91168^{\mathrm{T}}$ represents a novel species in the genus Saccharopolyspora, for which we propose the name Saccharopolyspora qijiaojingensis sp. nov.

\section{Description of Saccharopolyspora qijiaojingensis sp. nov.}

Saccharopolyspora qijiaojingensis (qi.jiao'jing.en'sis. N.L. fem. adj. qijiaojingensis pertaining to Qijiaojing Lake, Xinjiang Province, north-west China, where the sample from which the type strain was isolated was collected).

Aerobic, Gram-positive-staining, moderately halophilic, filamentous actinomycete. Substrate mycelium is welldeveloped and fragments into rod-shaped elements. Aerial mycelium is less abundant and forms bead-like chains of spores; spores are non-motile and smooth-surfaced, 0.6$0.7 \times 0.7-1.1 \mu \mathrm{m}$. Temperature, $\mathrm{pH}$ and $\mathrm{NaCl}$ ranges for growth are $20-40{ }^{\circ} \mathrm{C}, \mathrm{pH} 5.0-8.0$ and $6-22 \%(\mathrm{w} / \mathrm{v}) \mathrm{NaCl}$; optimal growth occurs at $28{ }^{\circ} \mathrm{C}, \mathrm{pH} 7.0$ and $10-15 \%(\mathrm{w} / \mathrm{v})$ $\mathrm{NaCl}$. Gelatin, hypoxanthine, Tween 20 and xanthine are degraded, but aesculin, casein, starch, cellulose, chitin, Tween 80, adenine, L-tyrosine and urea are not. Test for gelatin liquefaction is positive; tests for nitrate reduction, milk peptonization and coagulation, $\mathrm{H}_{2} \mathrm{~S}$ and melanin production and starch hydrolysis are negative. Lactose, Dmannitol, D-mannose, L-rhamnose, D-galactose, maltose and trehalose are utilized as sole carbon sources, while Larabinose, cellobiose, D-fructose, glycerol, glycogen, sucrose, starch and D-xylose are not. Growth is observed on DL-alanine, L-proline, hypoxanthine, L-histidine, L-asparagine, xanthine and L-hydroxyproline as nitrogen sources; growth is not observed on L-lysine, L-serine, adenine, Ltyrosine or L-phenylalanine. Sensitive to the following antibiotics ( $\mu \mathrm{g}$ per disc): amoxicillin (10), ampicillin (10), tetracycline (30), rifampicin (5), erythromycin (15), ciprofloxacin (5), chloramphenicol (30) and vancomycin (30). Resistant to ( $\mu \mathrm{g}$ per disc) tobramycin (10), gentamicin (10), streptomycin (10) and sulfamethoxazole/trimethoprim (23.75/1.25). The predominant menaquinone is MK- $9\left(\mathrm{H}_{4}\right)$. Major cellular fatty acids are iso- $\mathrm{C}_{15: 0}$, iso- 


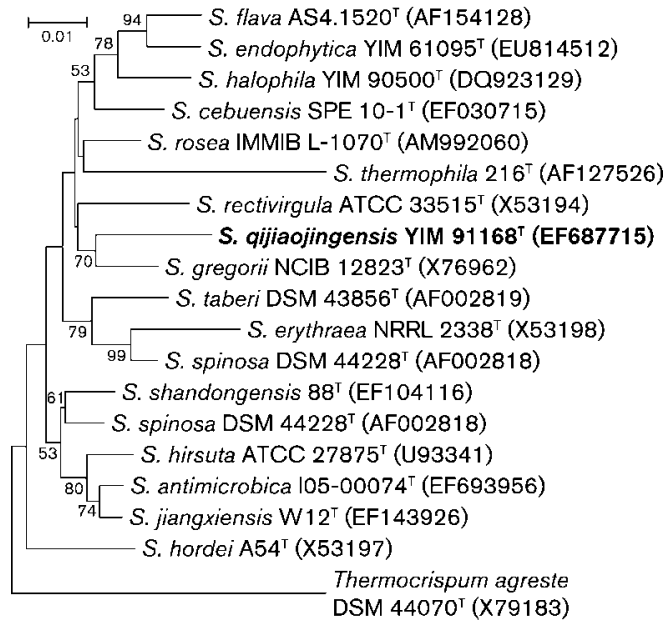

Fig. 2. Phylogenetic dendrogram obtained by distance matrix analysis of $16 \mathrm{~S}$ rRNA gene sequences, showing the position of strain YIM $91168^{\top}$ and its phylogenetic neighbours. Numbers on branch nodes are bootstrap percentages (1000 resamplings; only values over $50 \%$ are given). The sequence of Thermocrispum agreste DSM $44070^{\top}$ was used as outgroup. Bar, $1 \%$ sequence divergence.

$\mathrm{C}_{16: 0}$ and iso- $\mathrm{C}_{17: 0}$. The $\mathrm{G}+\mathrm{C}$ content of the DNA of the type strain is $70.1 \mathrm{~mol} \%$.

The type strain is YIM $91168^{\mathrm{T}}$ (=DSM $45088^{\mathrm{T}}=\mathrm{KCTC}$ $19235^{\mathrm{T}}$ ), isolated from a salt lake in Xinjiang Province, north-west China.

\section{Acknowledgements}

The authors are grateful to the anonymous reviewers for their helpful comments. This research was supported by the National Basic Research Program of China (no. 2004CB719601), the National Natural Science Foundation of China (nos 30600001, 30860002, 30870005), the Yunnan Provincial International Cooperative Program (no. 2005GH21), the Ministry of Science of Technology, PR China (2006DFA33550), and the Youth Technological Innovation Foundation of Xinjiang Academy of Agricultural Science (no. 2007Q07). W.-J. L. was supported by the Program for New Century Excellent Talents in University.

\section{References}

Chun, J., Lee, J.-H., Jung, Y., Kim, M., Kim, S., Kim, B. K. \& Lim, Y. W. (2007). EzTaxon: a web-based tool for the identification of prokaryotes based on 16S ribosomal RNA gene sequences. Int J Syst Evol Microbiol 57, 2259-2261.

Felsenstein, J. (1981). Evolutionary trees from DNA sequences: a maximum likelihood approach. J Mol Evol 17, 368-376.

Felsenstein, J. (1985). Confidence limits on phylogenies: an approach using the bootstrap. Evolution 39, 783-791.

Fitch, W. M. (1971). Toward defining the course of evolution: minimum change for a specific tree topology. Syst Zool 20, 406-416.
Goodfellow, M., Lacey, J., Athalye, M., Embley, T. M. \& Bowen, T. (1989). Saccharopolyspora gregorii and Saccharopolyspora hordei: two new actinomycete species from fodder. J Gen Microbiol 135, 21252139.

Hasegawa, T., Takizawa, M. \& Tanida, S. (1983). A rapid analysis for chemical grouping aerobic actinomycetes. J Gen Appl Microbiol 29, 319-322.

Kelly, K. L. (1964). Inter-Society Color Council-National Bureau of Standards Color Name Charts Illustrated with Centroid Colors. Washington, DC: US Government Printing Office.

Kimura, M. (1980). A simple method for estimating evolutionary rates of base substitutions through comparative studies of nucleotide sequences. J Mol Evol 16, 111-120.

Korn-Wendisch, F., Kempf, A., Grund, E., Kroppenstedt, R. M. \& Kutzner, H. J. (1989). Transfer of Faenia rectivirgula Kurup and Agre 1983 to the genus Saccharopolyspora Lacey and Goodfellow 1975, elevation of Saccharopolyspora hirsuta subsp. taberi Labeda 1987 to species level, and emended description of the genus Saccharopolyspora. Int J Syst Bacteriol 39, 430-441.

Kroppenstedt, R. M. (1982). Separation of bacterial menaquinones by HPLC using reverse phase (RP18) and a silver loaded ion exchanger as stationary phases. J Liq Chromatogr 5, 2359-2387.

Kroppenstedt, R. M. (1985). Fatty acid and menaquinone analysis of actinomycetes and related organisms. In Chemical Methods in Bacterial Systematics (Society for Applied Bacteriology Technical Series vol. 20), pp. 173-199. Edited by M. Goodfellow \& D. E. Minnikin. New York: Academic Press.

Labeda, D. P. (1987). Transfer of the type strain of Streptomyces erythraeus (Waksman 1923) Waksman and Henrici 1948 to the genus Saccharopolyspora Lacey and Goodfellow 1975 as Saccharopolyspora erythraea sp. nov., and designation of a neotype strain for Streptomyces erythraeus. Int J Syst Bacteriol 37, 19-22.

Lacey, J. \& Goodfellow, M. (1975). A novel actinomycete from sugarcane bagasse: Saccharopolyspora hirsuta gen. et sp. nov. J Gen Microbiol 88, 75-85.

Lechevalier, H. A. \& Lechevalier, M. P. (1970). A critical evaluation of the genera of aerobic actinomycetes. In The Actinomycetales, pp. 393405. Edited by H. Prauser. Jena: VEB Gustav Fischer.

Lechevalier, M. P., De Bièvre, C. \& Lechevalier, H. A. (1977). Chemotaxonomy of aerobic actinomycetes: phospholipid composition. Biochem Syst Ecol 5, 249-260.

Li, W.-J., Xu, P., Schumann, P., Zhang, Y.-Q., Pukall, R., Xu, L.-H., Stackebrandt, E. \& Jiang, C.-L. (2007). Georgenia ruanii sp. nov., a novel actinobacterium isolated from forest soil in Yunnan (China), and emended description of the genus Georgenia. Int J Syst Evol Microbiol 57, 1424-1428.

Marmur, J. (1961). A procedure for the isolation of deoxyribonucleic acid from microorganisms. J Mol Biol 3, 208-218.

Mesbah, M., Premachandran, U. \& Whitman, W. B. (1989). Precise measurement of the $\mathrm{G}+\mathrm{C}$ content of deoxyribonucleic acid by highperformance liquid chromatography. Int J Syst Bacteriol 39, 159-167.

Minnikin, D. E., O'Donnell, A. G., Goodfellow, M., Alderson, G., Athalye, M., Schaal, A. \& Parlett, J. H. (1984). An integrated procedure for the extraction of bacterial isoprenoid quinones and polar lipids. J Microbiol Methods 2, 233-241.

Pimentel-Elardo, S. M., Tiro, L. P., Grozdanov, L. \& Hentsche, U. (2008). Saccharopolyspora cebuensis sp. nov., a novel actinomycete isolated from a Philippine sponge (Porifera). Int J Syst Evol Microbiol 58, 628-632.

Qin, S., Li, J., Zhao, G. Z., Chen, H. H., Xu, L. H. \& Li, W. J. (2008). Saccharopolyspora endophytica sp. nov., an endophytic actinomycete 
isolated from the root of Maytenus austroyunnanensis. Syst Appl Microbiol 31, 352-357.

Saitou, N. \& Nei, M. (1987). The neighbor-joining method: a new method for reconstructing phylogenetic trees. Mol Biol Evol 4, 406425.

Sasser, M. (1990). Identification of bacteria by gas chromatography of cellular fatty acids. USFCC Newsl 20, 16.

Shirling, E. B. \& Gottlieb, D. (1966). Methods for characterization of Streptomyces species. Int J Syst Bacteriol 16, 313-340.

Tamura, K., Dudley, J., Nei, M. \& Kumar, S. (2007). MEGA4: molecular evolutionary genetics analysis (MEGA) software version 4.0. Mol Biol Evol 24, 1596-1599.

Tang, S.-K., Tian, X.-P., Zhi, X.-Y., Cai, M., Wu, J.-Y., Yang, L.-L., Xu, L.-H. \& Li, W.-J. (2008). Haloactinospora alba gen. nov., sp. nov., a halophilic filamentous actinomycete of the family Nocardiopsaceae. Int J Syst Evol Microbiol 58, 2075-2080.

Tang, S.-K., Wang, Y., Cai, M., Zhi, X.-Y., Lou, K., Xu, L.-H., Jiang, C.-L. \& Li, W.-J. (2009). Saccharopolyspora halophila sp. nov., a novel halophilic actinomycete isolated from a saline lake in China. Int J Syst Evol Microbiol 59, 555-558.
Williams, S. T. (1967). Sensitivity of streptomycetes to antibiotics as a taxonomic character. J Gen Microbiol 46, 151-160.

Williams, S. T., Goodfellow, M. \& Alderson, G. (1989). Genus Streptomyces Waksman and Henrici 1943, 339 ${ }^{\mathrm{AL}}$. In Bergey's Manual of Systematic Bacteriology, vol. 4, pp. 2463-2468. Edited by S. T. Williams, M. E. Sharpe \& J. G. Holt. Baltimore: Williams \&Wilkins. Yassin, A. F. (2009). Saccharopolyspora rosea sp. nov., isolated from a patient with bronchial carcinoma. Int J Syst Evol Microbiol 59, 1148-1152.

Yuan, L.-J., Zhang, Y.-Q., Guan, Y., Wei, Y.-Z., Li, Q.-P., Yu, L.-Y., Li, W.-J. \& Zhang, Y.-O. (2008). Saccharopolyspora antimicrobica sp. nov., an actinomycete from soil. Int J Syst Evol Microbiol 58, 1180-1185.

Zhang, J., Wu, D., Zhang, J., Liu, Z. \& Song, F. (2008). Saccharopolyspora shandongensis sp. nov., isolated from wheat-field soil. Int J Syst Evol Microbiol 58, 1094-1099.

Zhang, J., Wu, D. \& Liu, Z. (2009). Saccharopolyspora jiangxiensis sp. nov., isolated from grass-field soil. Int J Syst Evol Microbiol 59, 10761081 .

Zhou, Z.-H., Liu, Z.-H., Qian, Y.-D., Kim, S. B. \& Goodfellow, M. (1998). Saccharopolyspora spinosporotrichia sp. nov., a novel actinomycete from soil. Int J Syst Bacteriol 48, 53-58. 